(c) 2020, The Authors. Published by FASS Inc. and Elsevier Inc. on behalf of the American Dairy Science Association ${ }^{\circledR}$. This is an open access article under the CC BY-NC-ND license (http://creativecommons.org/licenses/by-nc-nd/4.0/).

\title{
Enteric methane emission and digestion in dairy cows fed wheat or molasses
}

\author{
C. F. Børsting, ${ }^{*} \odot$ M. Brask, $\odot$ A. L. F. Hellwing, $\odot$ M. R. Weisbjerg, $\odot$ and P. Lund $\odot$ \\ Department of Animal Science, AU Foulum, Aarhus University, PO Box 50, DK 8830 Tjele, Denmark
}

\begin{abstract}
The aim of this experiment was to measure enteric methane $\left(\mathrm{CH}_{4}\right)$ emission and its relation with rumen digestion in dairy cows fed diets rich in 1 of the 2 carbohydrate sources, starch or sugar. The rations were based on late first-cut grass-clover silage supplemented with wheat $(\mathrm{Wh}), \mathrm{NaOH}$-treated wheat $(\mathrm{Wh}+\mathrm{NaOH})$, sugar beet molasses (Mo), or sugar beet molasses with addition of sodium bicarbonate (Mo+Bic). Wheat and molasses made up $35 \%$ of dry matter in the 2 diets with molasses and wheat, respectively. Four cows fitted with ruminal, duodenal, and ileal canulae were used in a $4 \times 4$ Latin square design. Nutrient digestibility was measured using chromium oxide and titanium oxide as flow markers, and emissions of $\mathrm{CH}_{4}$ and hydrogen were measured via open-circuit indirect calorimetry on 4 consecutive days. Data were analyzed using PROC MIXED of SAS (version 9.4; SAS Institute Inc., Cary, $\mathrm{NC}$ ) with treatment and period as fixed effects and cow as random effect. Furthermore, orthogonal contrasts were calculated. The cows produced 32.5, 33.6, 36.2, and $35.1 \mathrm{~L}$ of $\mathrm{CH}_{4} / \mathrm{kg}$ of dry matter intake (DMI) on diets $\mathrm{Wh}, \mathrm{Wh}+\mathrm{NaOH}, \mathrm{Mo}$, and $\mathrm{Mo}+\mathrm{Bic}$, respectively. The emission of $\mathrm{CH}_{4}$ per day, per kilogram of DMI, and per kilogram of energy-corrected milk as well as daily hydrogen emission were higher on the Mo diet compared with the Wh diet. With the present inclusion of wheat and molasses in the diet, no effects of $\mathrm{NaOH}$ treatment of wheat or of sodium bicarbonate supplementation to the Mo diet could be demonstrated on $\mathrm{CH}_{4}$ emission expressed per kilogram of DMI or per kilogram of energy-corrected milk. The duodenal flow of starch was higher when wheat was treated with $\mathrm{NaOH}$. Under the conditions in the present experiment, ruminal NDF digestibility was not affected by carbohydrate source, $\mathrm{NaOH}$ treatment of wheat, or bicarbonate supplementation. Total volatile fatty acid concentration in the rumen and the proportions of acetate and propionate were not affected by carbohydrate source, $\mathrm{NaOH}$ treatment
\end{abstract}

Received March 20, 2019.

Accepted October 10, 2019

*Corresponding author: Christian.borsting@anis.au.dk of wheat, or bicarbonate supplementation. Likewise, we could not show any influence of diet on microbial protein synthesis or efficiency of microbial protein synthesis expressed as grams of microbial protein synthesis per kilogram of true rumen-digested organic matter. We concluded that $\mathrm{CH}_{4}$ emission was increased when wheat was replaced by molasses, whereas no effect of manipulating rumen fermentation by $\mathrm{NaOH}$ treatment of wheat or addition of bicarbonate to molasses could be found with a level of approximately $25 \%$ of dry matter from starch and sugar, respectively.

Key words: enteric methane, buffer, bicarbonate, mitigation strategy

\section{INTRODUCTION}

Enteric methane $\left(\mathrm{CH}_{4}\right)$ constitutes a significant part of the carbon footprint of ruminant products. It is well established that dietary carbohydrate (CHO) composition influences the rumen fermentation pattern and enteric $\mathrm{CH}_{4}$ production (Jentsch et al., 2007). Starch and sugar are both highly degradable in the rumen, but their rumen fermentation pathways differ, resulting in different VFA profiles and thereby different $\mathrm{CH}_{4}$ production. Starch and fiber are the quantitatively most important $\mathrm{CHO}$ fractions in most diets. Therefore, there has recently been an intense focus on the difference between starch and fiber in $\mathrm{CH}_{4}$ production and the effect of fiber source. Brask et al. (2013a) showed that replacing maize silage with grass silage as well as replacing lowfiber grass silage with high-fiber grass silage resulted in higher $\mathrm{CH}_{4}$ production per kilogram of $\mathrm{OM}$ fermented in the rumen, a higher proportion of acetic acid, and a lower proportion of propionic acid. According to Boadi et al. (2004), the higher propionic acid production on maize silage diets acts as an alternative hydrogen sink, reducing the amount of hydrogen transformed into $\mathrm{CH}_{4}$, whereas the higher acetate production on grass silage diets enhances $\mathrm{CH}_{4}$ production (Johnson and Johnson, 1995). Contrary to the multiple comparisons of starch and fiber in the diet, few studies have evaluated the effect of replacing starch with sugar. Hindrichsen et al. (2004) and Jentsch et al. (2007) showed that starch and sugar influence rumen fermentation, and therefore $\mathrm{CH}_{4}$ production, differently. Methane release in a Rusitec in 
vitro system was $1.04 \mathrm{mmol} / \mathrm{g}$ of degraded $\mathrm{OM}$ from wheat, whereas it was $1.37 \mathrm{mmol} / \mathrm{g}$ of degraded $\mathrm{OM}$ from molasses (Hindrichsen et al., 2004). High dietary starch content favors the proportion of propionate, whereas dietary sugar increases the proportion of butyrate (e.g., Jentsch et al., 2007), resulting in hydrogen $\left(\mathrm{H}_{2}\right)$ surplus and increased $\mathrm{CH}_{4}$ production (Ungerfeld and Kohn, 2006). However, the effect of sugar on $\mathrm{CH}_{4}$ production is $\mathrm{pH}$ dependent, as sugar increases $\mathrm{CH}_{4}$ production only when rumen $\mathrm{pH}$ is maintained at a high level (Hindrichsen and Kreuzer, 2009). Rumen pH also affects the fermentation pattern, as a decrease in $\mathrm{pH}$ favors propionate production and thereby reduces hydrogen available for $\mathrm{CH}_{4}$ production (Murphy et al., 1982). Rumen acidosis can be prevented by reducing the ruminal degradability of starch in the ration by chemical treatment of grains (Nozière et al., 2010), which moves some of the starch digestion to the small intestine (Larsen et al., 2009). Furthermore, a buffer (e.g., sodium bicarbonate) can be added to the diet to stabilize $\mathrm{pH}$ and in this way prevent rumen acidosis.

At intensive fermentation rates of quickly degradable nutrients, such as starch and sugar, rumen $\mathrm{pH}$ decreases, leading to a lower $\mathrm{CH}_{4}$ production due to inhibition of fibrolytic bacteria and methanogens as well as enhanced propionate production (Beauchemin et al., 2008). It is therefore unclear whether the methanogenic properties of starch and sugar can be characterized merely by their content in a given diet or whether this effect interacts with the overall rumen $\mathrm{pH}$. Elucidating this interaction between rumen $\mathrm{pH}$ and $\mathrm{CHO}$ source with respect to enteric $\mathrm{CH}_{4}$ is essential, as a wide range of prediction equations based merely on chemical composition of the diets have been published recently. These equations seem to have problems accounting for the variation between diets if only production level and dietary chemical composition are taken into account.

We hypothesized that a diet rich in starch from wheat would lead to lower $\mathrm{CH}_{4}$ emissions than a diet with an equivalent amount of sugar from molasses due to a higher production of propionate and a lower production of butyrate in the rumen. Furthermore, we expected to achieve a higher ruminal $\mathrm{pH}$ when wheat was treated with $\mathrm{NaOH}$ and when bicarbonate was added to the molasses diet.

The first aim of this experiment was to examine the effect of starch and sugar on ruminal and intestinal metabolism and enteric $\mathrm{CH}_{4}$ production. Furthermore, the effects on these parameters were examined when we attempted to modify the rumen environment either by feeding $\mathrm{NaOH}$-treated whole-kernel wheat to affect the ruminal starch degradation and $\mathrm{pH}$ or by adding sodium bicarbonate to a diet with sugar from molasses to manipulate the rumen $\mathrm{pH}$ in a different way.

\section{MATERIALS AND METHODS}

\section{Animals and Diets}

The experiment complied with the guidelines of the Danish Ministry of Justice with respect to animal experimentation and care of animals under study. Four lactating Danish Holstein dairy cows (3 primiparous and 1 multiparous) were assigned to 1 of 4 rations over 4 periods according to a balanced $4 \times 4$ Latin square design. Each period consisted of $4 \mathrm{wk}$.

On average, the cows were 176 DIM $(\mathrm{SD}=158 \mathrm{~d})$ and had a milk yield of $27.2 \mathrm{~kg}(\mathrm{SD}=8.3 \mathrm{~kg})$ and a BW of $548 \mathrm{~kg}(\mathrm{SD}=38 \mathrm{~kg})$ at the beginning of the experiment. All animals were fitted with a ruminal cannula (no. 1C; Bar Diamond Inc., Parma, ID), a duodenal cannula (open T-piece placed $60 \mathrm{~cm}$ caudal to the pylorus), and an ileal cannula (open T-piece placed 20 $\mathrm{cm}$ cranial to the cecum). The cows were housed in a tiestall with rubber mats and had free access to water. They were milked twice daily at 0600 and $1700 \mathrm{~h}$. Total mixed rations were prepared once a day and fed to the cows on an ad libitum basis at 0630 and $1630 \mathrm{~h}$. The feed intake was recorded on a daily basis, and orts were removed in the morning just before feeding. Twice daily, throughout the experiment, $10 \mathrm{~g}$ of chromium oxide $\left(\mathrm{Cr}_{2} \mathrm{O}_{3}\right)$ and $13 \mathrm{~g}$ of titanium oxide $\left(\mathrm{TiO}_{2}\right)$ were placed in the rumen via the ruminal cannula in connection with feeding, except when the cows were in the respiration chambers.

The rations were formulated according to the Norfor feed evaluation system (Volden, 2011), and they contained concentrates based on rolled wheat (Wh), $\mathrm{NaOH}$-treated whole-wheat kernels $(\mathbf{W h}+\mathbf{N a O H})$, beet molasses (Mo), or beet molasses plus sodium bicarbonate $(\mathbf{M o}+\mathbf{B i c})$. Other dietary ingredients were soybean meal, mineral and vitamin supplements, and late first-cut grass-clover silage with a low $(<10 \%$ of DM) clover proportion [chemical composition: 511, 80, and $123 \mathrm{~g} / \mathrm{kg}$ DM of NDF, indigestible NDF (iNDF), and protein, respectively, and an OM digestibility of $69.9 \%$ calculated in vivo, based on in vitro OM digestibility of $68.6 \%$; Akerlind et al., 2011]. The dietary composition of the 4 diets is given in Table 1. Sodium hydroxide treatment of wheat was performed by adding $3.0 \mathrm{~kg}$ of $\mathrm{NaOH}$ and $8.0 \mathrm{~kg}$ of water $/ 100 \mathrm{~kg}$ of wheat, followed by mixing. The rations were mixed once daily and fed as TMR with a forage:concentrate ratio of 49:51 on a DM basis.

\section{Sampling and Recordings}

Milk yield was measured daily, and composition was measured once a week during the morning and evening 
Table 1. Dietary and chemical composition ( $\mathrm{g} / \mathrm{kg}$ of DM unless otherwise noted) of the 4 experimental $\operatorname{diets}^{1}$

\begin{tabular}{|c|c|c|c|c|}
\hline Item & Wh & $\mathrm{Wh}+\mathrm{NaOH}$ & Mo & $\mathrm{Mo}+\mathrm{Bic}$ \\
\hline \multicolumn{5}{|l|}{ Composition of rations } \\
\hline Grass-clover silage $^{2}$ & 494 & 490 & 494 & 490 \\
\hline Wheat & 353 & & & \\
\hline $\mathrm{NaOH}$-treated wheat & & 359 & & \\
\hline Sugar beet molasses & & & 353 & 350 \\
\hline $\mathrm{NaHCO}_{3}$ & & & & 9.3 \\
\hline Soybean meal & 141 & 140 & 141 & 140 \\
\hline Minerals and vitamins & 12 & 12 & 12 & 12 \\
\hline DM in diets, $\mathrm{g} / \mathrm{kg}$ & 473 & 471 & 450 & 453 \\
\hline \multicolumn{5}{|l|}{ Chemical composition } \\
\hline Ash & 60.6 & 74.6 & 97.5 & 103 \\
\hline $\mathrm{CP}$ & 175 & 176 & 178 & 180 \\
\hline Crude fat & 25.8 & 24.4 & 16.5 & 16.7 \\
\hline Fatty acids & 17.0 & 17.0 & 11.0 & 11.0 \\
\hline Starch & 227 & 249 & 14.0 & 12.0 \\
\hline Sugar & 34.2 & 30.0 & 241 & 238 \\
\hline NDF & 318 & 290 & 280 & 277 \\
\hline Sodium ${ }^{3}$ & 1.9 & 7.0 & 3.2 & 5.7 \\
\hline Potassium $^{3}$ & 19.2 & 19.1 & 27.0 & 26.8 \\
\hline Chloride $^{3}$ & 8.3 & 8.2 & 9.4 & 9.3 \\
\hline Sulfur $^{3}$ & 2.4 & 2.4 & 3.4 & 3.3 \\
\hline $\mathrm{CAB},{ }^{3,4} \mathrm{mEq} / \mathrm{kg}$ of $\mathrm{DM}$ & 175 & 399 & 340 & 446 \\
\hline Gross energy, MJ/kg of DM & 18.2 & 18.0 & 17.4 & 17.3 \\
\hline
\end{tabular}

${ }^{1}$ The rations were based on late first-cut grass-clover silage supplemented with wheat (Wh), NaOH-treated wheat $(\mathrm{Wh}+\mathrm{NaOH})$, sugar beet molasses $(\mathrm{Mo})$, or sugar beet molasses with addition of sodium bicarbonate (Mo+Bic).

${ }^{2}$ DM: $325 \mathrm{~g} / \mathrm{kg}$; NDF: $511 \mathrm{~g} / \mathrm{kg}$ of DM; CP: $123 \mathrm{~g} / \mathrm{kg}$ of DM.

${ }^{3}$ Feed table values (Møller et al., 2005).

${ }^{4} \mathrm{CAB}$ (cation-anion balance): $(\mathrm{mEq} / \mathrm{kg}$ of $\mathrm{DM})=[(\mathrm{Na} / 23.0+\mathrm{K} / 39.1)-(\mathrm{Cl} / 35.5+\mathrm{S} / 16.0)] \times 1,000$, where $\mathrm{Na}, \mathrm{K}, \mathrm{Cl}$, and $\mathrm{S}$ are given as $\mathrm{g} / \mathrm{kg}$ of $\mathrm{DM}$.

milkings. Milk data are given for only the last week of the 4 experimental weeks in each period. The animals were weighed at the beginning of the experiment as well as just before and after the respiration chamber measurements. Samples of the mixed diets and refusals were taken daily in connection with the morning feeding from d 15 to 20 in each period, and DM was measured daily for both diets and refusals from each cow. Samples of diets were stored at $-20^{\circ} \mathrm{C}$ and pooled within each period before chemical analyses.

Twelve samples, representing every second hour of the day, were taken of duodenal chyme $(600 \mathrm{~mL})$, ileal chyme $(300 \mathrm{~mL})$, and feces $(350 \mathrm{~mL})$ from d 15 to 19 at 1000 and $1800 \mathrm{~h}$ on d $15 ; 0200,1200$, and $2000 \mathrm{~h}$ on d 16;0400, 1400, and $2200 \mathrm{~h}$ on d 17; 0600, 1600, and $2400 \mathrm{~h}$ on d 18; and $0800 \mathrm{~h}$ on d 19. Samples from the duodenum and ileum were taken in tube-formed plastic bags mounted to the cannulas. At each sampling time, duodenal, ileal, and fecal samples were added to the frozen pooled sample from previous samplings during the same period. At the end of the period, representative subsamples from thawed material were taken and freeze-dried before chemical analyses. At the 12 sampling times, rumen liquid was sampled from the ventral ruminal sac with a collection tube (no. RT, Bar
Diamond Inc.). The rumen liquid $\mathrm{pH}$ was measured immediately, and 2 samples of $8 \mathrm{~mL}$ were taken and frozen $\left(-20^{\circ} \mathrm{C}\right)$ immediately for VFA and ammonia $\left(\mathrm{NH}_{3}\right)$ analysis.

Total rumen evacuations were performed approximately $5 \mathrm{~h}$ after feeding at $1200 \mathrm{~h}$ on the last day (d 28) in each period. Rumen content was divided in mat and free fluid fractions using a sieve basket, and the weight of each fraction was recorded before subsampling and compositing a pooled sample by weight for DM determination $\left(60^{\circ} \mathrm{C}\right)$. Rumen liquid was collected from the liquid phase using a cup, filtered over 2 layers of cheesecloth, and transferred to prewarmed vacuum-insulated bottles. Samples were taken directly to the laboratory and handled according to the standard procedure of our laboratory (Brask et al., 2015). Feed particles and protozoa were removed by double centrifugation at 500 $\times g$ for $5 \mathrm{~min}$ at $3^{\circ} \mathrm{C}$. The supernatant was collected and centrifuged at $17,300 \times g$ for $20 \mathrm{~min}$ at $3^{\circ} \mathrm{C}$. Then, the pellet was collected and resuspended in $200 \mathrm{~mL}$ of $\mathrm{NaCl}(9 \%)$ and centrifuged at $17,300 \times g$ for 20 min at $3^{\circ} \mathrm{C}$. Next, the pellet (microbial matter) was stored at $-20^{\circ} \mathrm{C}$. Finally, the microbial matter was freeze-dried and analyzed for ash, nitrogen, and purine content to calculate microbial CP synthesis and efficiency. 


\section{Chemical Analyses}

Dry matter of feeds and rumen samples was determined after $48 \mathrm{~h}$ at $60^{\circ} \mathrm{C}$. Ash was determined by combustion at $525^{\circ} \mathrm{C}$ for $6 \mathrm{~h}$. Nitrogen was determined using the Dumas principle (Hansen, 1989), and the CP was calculated as $\mathrm{N} \times 6.25$. Crude fat was analyzed as Soxhlet extraction with petroleum ether (Soxtec 2050, Foss Analytical, Hillerød, Denmark) after hydrolyzing with $\mathrm{HCl}$ (Stoldt, 1952).

Starch content in feed, digesta, and feces was determined enzymatically (Kristensen et al., 2007). Total sugar was determined using the Luff-Schoorl method (European Community, 2012).

The NDF content was analyzed using neutral detergent extraction according to Mertens (2002) with a Fibertec M6 System (Foss Analytical) using heat-stable amylase and corrected for ash. The iNDF in freezedried ground $(1.5 \mathrm{~mm})$ feed samples was determined as residual NDF after $288 \mathrm{~h}(12 \mathrm{~d})$ of Dacron bag $(12-\mu \mathrm{m}$ pore size; TP Filter, Upplands Väsby, Sweden) incubation in the rumen of 3 heifers fed a standard ration (Åkerlind et al., 2011). Gross energy was determined using an adiabatic bomb calorimeter (Parr 6300 Oxygen Bomb Calorimeter, Parr Instrument Co., Moline, IL).

The concentrations of VFA were analyzed according to the method described by Canibe et al. (2007) using a gas chromatograph (model 6890; Hewlett Packard, Palo Alto, CA) equipped with a flame ionization detector and a 30-m SGE BP1 column (Scientific Instrument Services, Ringoes, NJ). For determination of $\mathrm{NH}_{3}-\mathrm{N}$, the rumen fluid was made alkaline with $\mathrm{KOH}$, and $\mathrm{NH}_{3}-\mathrm{N}$ was determined by titration after distillation.

Chromium oxide was determined by spectrophotometry after oxidation to chromate (Schürch et al., 1950). Titanium oxide was analyzed according to Myers et al. (2004) with the exception that $15 \mathrm{~mL}$ of $30 \% \mathrm{H}_{2} \mathrm{O}_{2}$ was added instead of $10 \mathrm{~mL}$, and 5 drops of $30 \% \mathrm{H}_{2} \mathrm{O}_{2}$ were added to the solution just before measuring the absorbance. The OM digestibility was determined in vitro for grass silage as described by Tilley and Terry (1963). Milk concentrations of fat, protein, and lactose monohydrate were analyzed by a Milkoscan Msc4000 infrared analyzer (Foss Analytical).

\section{Methane Measurements}

During the fourth week of each period, $\mathrm{CH}_{4}$ production was measured for $2 \times 48 \mathrm{~h}$ in 4 open-circuit polycarbonate respiration chambers with a volume of $17 \mathrm{~m}^{3}$ (Hellwing et al., 2012). The animals were housed individually. The chambers were located in the barn where the cows were usually housed to minimize changes in the environment, and the daily routines during the $\mathrm{CH}_{4}$ measurements were identical to the period outside the chambers. The mean ambient temperature in the chambers was $21.1^{\circ} \mathrm{C}$, ranging from 15.6 to $29.5^{\circ} \mathrm{C}$.

The cows changed chambers diagonally after the first $48 \mathrm{~h}$ to balance out any differences in background levels of $\mathrm{CH}_{4}$ and $\mathrm{CO}_{2}$. Cow and chamber were confounded over periods, and therefore every ration was tested in every chamber. Chambers were opened twice daily at 0600 and $1700 \mathrm{~h}$ for about 20 min during milking and subsequent feeding. Methane was measured as the accumulated amount in liters over $24 \mathrm{~h}$ and is reported under standard conditions $\left(0^{\circ} \mathrm{C}, 101.325 \mathrm{kPa}\right)$, where 1 mol of $\mathrm{CH}_{4}$ is equal to $22.41 \mathrm{~L}$ (Brouwer, 1965). The measurements during the openings of the chambers for milking and feeding were deleted (about $60 \mathrm{~min} / \mathrm{d}$ ). The $\mathrm{CH}_{4}$ production during these periods was replaced by values corresponding to the mean value for the rest of the day. Airflow was measured using a HFM-200 flow meter with a laminar flow element from Teledyne Hastings Instruments (Hampton, VA). The background (inlet air) as well as the chamber outlet air concentration of $\mathrm{CH}_{4}$ was measured for $30 \mathrm{~s}$ every $12.5 \mathrm{~min}$ in each chamber. Before each measurement, the measuring system was flushed with sample air either from background or chamber for 2 min before the gas sample was measured for $30 \mathrm{~s}$. Methane and $\mathrm{CO}_{2}$ were measured with an infrared analyzer. All instruments were from Columbus Instruments (Columbus, $\mathrm{OH}$ ). The airflow was adjusted individually for each animal depending on their BW and milk yield to obtain a $\mathrm{CO}_{2}$ concentration in the chamber below but close to $9,000 \mathrm{ppm}$. The instruments were calibrated every second day with zero gas (nitrogen) and a span gas with nitrogen and $20.55 \% \mathrm{O}_{2}, 5,000 \mathrm{ppm}$ of $\mathrm{CO}_{2}$, and $800 \mathrm{ppm}$ of $\mathrm{CH}_{4}$ (Yara Praxair AS, Oslo, Norway). Recovery of $\mathrm{CH}_{4}$ was measured 6 times during the experiment and was on average $97 \%$. Data were not corrected for recovery due to the high recovery.

\section{Calculations and Statistical Analyses}

Dry matter flow was calculated as the average flow determined using the 2 external markers independently. For each of the 2 markers, DM flow was calculated from marker dosage and marker concentrations in duodenal and ileal digesta and in feces, assuming 100\% recovery of the markers in digesta and feces. Flow of nutrients was subsequently calculated based on dry matter flow and nutrient concentration. Content of digestible NDF (dNDF) was calculated as NDF - iNDF. Rumen fractional rate of passage of iNDF was calculated as intake of iNDF $(\mathrm{kg} / \mathrm{h}$; assuming that intake of iNDF equals rumen output) divided by rumen iNDF pool 
$(\mathrm{kg})$. Rumen fractional rate of digestion of dNDF was calculated as duodenal flow of dNDF $(\mathrm{kg} / \mathrm{h})$ divided by rumen dNDF pool (kg; Robinson et al., 1987). Rumen pool was determined based on total rumen evacuation and chemical analysis of a representative subsample.

Microbial synthesis of DM and CP was calculated from the DM, N, and purine concentration in rumenisolated bacteria, purine concentration in duodenal DM content, DM flow at the duodenum, and ratio between purine and the given nutrient in the isolated microbial pellet, assuming that all purines flowing at the duodenum originate from rumen microbes (Zinn and Owens, 1986). Microbial efficiency was calculated as microbial $\mathrm{CP}$ synthesized divided by true rumen-digested OM, where true rumen-digested $\mathrm{OM}$ was calculated as $\mathrm{OM}$ intake with feed minus duodenal OM flow (corrected for microbial OM flow at the duodenum; Madsen and Hvelplund, 1988).

Apparent ruminal digestibility of each nutrient was calculated as nutrient intake minus duodenal nutrient flow divided by nutrient intake. Apparent total-tract digestibility of each nutrient was calculated as the nutrient intake minus fecal nutrient flow divided by nutrient intake.

Average ECM (defined as $3.14 \mathrm{MJ} / \mathrm{kg}$ ) yield for each cow per period was calculated according to Sjaunja et al. (1991) as

$$
\begin{aligned}
\mathrm{ECM} & =\text { milk yield } \times(383 \times \text { fat } \%+242 \\
& \times \text { protein } \%+783.2) / 3,140 .
\end{aligned}
$$

For data on feed intake, milk yield, milk composition, digestibility, microbial protein synthesis, passage rate, and gas exchange per day, data were analyzed in SAS (version 9.4; SAS Institute Inc., Cary, NC) using PROC MIXED with treatment and period as fixed effects and cow as random effect.

For data on rumen $\mathrm{pH}$, rumen VFA composition, $\mathrm{NH}_{3}-\mathrm{N}$ concentration, and gas exchange data based on hourly values, a mixed model with repeated measurement in SAS was also used with treatment, period, time, and treatment $\times$ time as fixed effects. Time was repeated effect per cow per period. For all variables, compound symmetry and autoregressive 1 were tested as covariance structure, and the covariance structure giving the lowest Akaike information criterion and Bayesian information criterion values was chosen. For all reported values, the lowest Akaike information criterion and Bayesian information criterion values were found for compound symmetry.

The default estimation method for PROC MIXED in SAS, which is restricted maximum likelihood, was used to estimate the covariance parameters. The de- nominator's degree of freedom was estimated with the Satterthwaite approximation.

The results are reported as LSM and SEM values for each treatment. Besides the mean treatment effect, the significance of orthogonal contrasts was calculated for Wh versus Mo (effect of CHO source), Wh versus $\mathrm{Wh}+\mathrm{NaOH}$ (effect of $\mathrm{NaOH}$ treatment), and Mo versus $\mathrm{Mo}+\mathrm{Bic}$ (effect of addition of sodium bicarbonate). $P$ values $<0.05$ were regarded as significant, and $P$-values of $0.05<P<0.10$ were regarded as a tendency.

\section{RESULTS}

\section{Feed Intake and Digestibility}

Dry matter intake was significantly lower for the Wh diet $(16.6 \mathrm{~kg})$ compared with the Mo $(17.9 \mathrm{~kg}$; $P=0.04)$ and $\mathrm{Wh}+\mathrm{NaOH}(18.1 \mathrm{~kg} ; P=0.03)$ diets, whereas DMI was equal for the 2 molasses diets, Mo and $\mathrm{Mo}+\mathrm{Bic}(17.7 \mathrm{~kg} ; P=0.70$; Table 2). Water intake was lower for the Wh diet $(67.8 \mathrm{~kg})$ than for the $\mathrm{Wh}+\mathrm{NaOH} \operatorname{diet}(81.4 \mathrm{~kg} ; P=0.005)$ and for the Mo $\operatorname{diet}(88.2 \mathrm{~kg} ; P=0.001)$, whereas adding bicarbonate to the molasses diet did not affect water intake.

Organic matter intake was lower in the Wh diet (15.6 $\mathrm{kg})$ than in the $\mathrm{Wh}+\mathrm{NaOH} \operatorname{diet}(16.7 \mathrm{~kg} ; P=0.05)$. Organic matter digestibility was not affected by diet in any part of the digestive tract, and OM total-tract digestibility was on average $75.8 \%$.

Intake of starch was highest on the 2 wheat-based diets (3.77 and $4.10 \mathrm{~kg})$ compared with the 2 diets with molasses $(0.26$ and $0.21 \mathrm{~kg})$. Rumen digestibility of starch was significantly reduced $(P=0.001)$ from $87.8 \%$ in the rolled wheat diet (Wh) to $69.7 \%$ in the diet with $\mathrm{NaOH}$-treated wheat, resulting in a significantly higher $(P<0.001)$ duodenal flow of starch of $1.12 \mathrm{~kg}$ in the $\mathrm{Wh}+\mathrm{NaOH}$ diet compared with $0.43 \mathrm{~kg}$ in the Wh diet. Rumen digestibility of the low intake of starch in the Mo diet was significantly $(32.3 \% ; P<0.001)$ lower than in the Wh diet (87.8\%). There was no effect of diet on the starch digestibility of the small intestine. Despite a numerically higher total-tract starch digestibility in the Wh diet (98.3\%) than in the Mo diet (93.3\%), the difference was not significant $(P=0.14)$. Sugar intake was higher for molasses diets (4.33 and $4.23 \mathrm{~kg}$ ) compared with wheat-based diets $(0.57$ and $0.54 \mathrm{~kg})$.

The intake of NDF was slightly higher for the Wh diet than for the $\mathrm{Wh}+\mathrm{NaOH}$ diet despite a lower DMI for the wheat diet because the $\mathrm{NaOH}$ treatment of wheat markedly decreased the NDF content from 140 to 80 $\mathrm{g} / \mathrm{kg}$ of DM in wheat. Total-tract digestibility of NDF was significantly lower in the Wh diet $(64.6 \%)$ than in the $\mathrm{Wh}+\mathrm{NaOH}(67.6 \% ; P=0.03)$ and $\mathrm{Mo}(67.9 \% ; P=$ $0.02)$ diets. There were no significant effects of $\mathrm{NaOH}$ 
treatment of wheat and of adding bicarbonate to the molasses diet on the rumen NDF digestibility.

The small intestinal digestibility of protein was higher in the Wh diet $(73.8 \%)$ than in the Mo diet $(65.0 \%$; $P$ $=0.005)$. However, there was no effect of treatment on total-tract digestibility of protein.

\section{Rumen Fermentation}

All measurements of total and individual VFA were significantly affected by the time of sampling $(P$ $<0.001$ ). Total VFA concentration and acetate and propionate proportions were unaffected by treatment (Table 3). The average diurnal butyrate proportion was numerically higher on the Mo diet (19.0\%) compared with the Wh diet (15.0\%). Butyrate proportion was higher for the Mo diet than for the Wh diet at all sampling times (Figure 1). Despite this, the mean proportion of butyrate was not significantly higher for the Mo diet than for the Wh diet $(P=0.14)$. There was no effect of $\mathrm{CHO}$ source on acetate plus butyrate: propionate ratio $(P=0.31)$. Isobutyrate was the only VFA showing a significant $(P<0.001)$ difference between the Mo $(0.52 \%)$ and Wh $(0.91 \%)$ diets. There was no effect of $\mathrm{NaOH}$ treatment of wheat or of bicarbonate supplementation to molasses on concentration of any of the measured VFA or the ratio between VFA, as shown in Table 3 .

There was no difference between the Wh and Mo diets for average and minimum $\mathrm{pH}$ in the ventral rumen. The $\mathrm{NaOH}$ treatment of wheat did not significantly affect average and minimum $\mathrm{pH}$ in the ventral rumen. Replacing wheat with molasses tended $(P=0.06)$ to reduce the number of the 12 observations per cow having a $\mathrm{pH}$ lower than 6.0. There was a tendency $(P=0.08)$ for $\mathrm{NaOH}$ treatment of wheat to reduce the number of observations with a $\mathrm{pH}$ lower than 6.0. Bicarbonate supplementation of the molasses diet did not affect average or minimum $\mathrm{pH}$ in the ventral rumen. The highest $\mathrm{pH}$ values were reached before the morning feeding at $0630 \mathrm{~h}$ (Figure 1). There was no effect of treatment $(P=0.63)$ on the ammonia- $\mathrm{N}\left(\mathrm{NH}_{3}-\mathrm{N}\right)$ concentration,

Table 2. Intake and apparent digestibility of nutrients

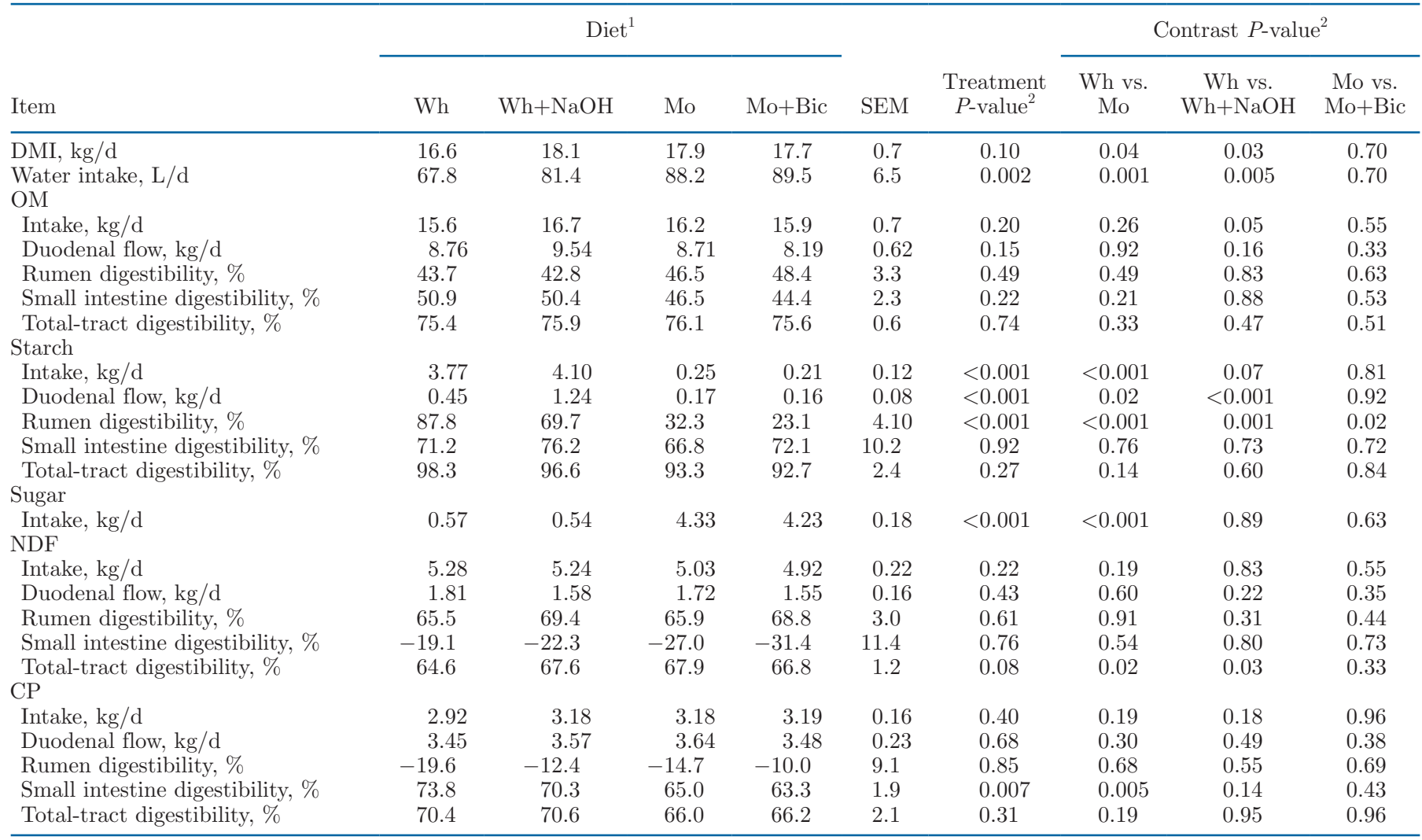

${ }^{1}$ The rations were based on late first-cut grass-clover silage supplemented with wheat $(\mathrm{Wh}), \mathrm{NaOH}$-treated wheat $(\mathrm{Wh}+\mathrm{NaOH})$, sugar beet molasses (Mo), or sugar beet molasses with addition of sodium bicarbonate (Mo+Bic).

${ }^{2} P$-values are given for the overall treatment effects and for orthogonal contrasts for Wh versus Mo (effect of carbohydrate source), Wh versus $\mathrm{Wh}+\mathrm{NaOH}$ (effect of $\mathrm{NaOH}$ treatment), and $\mathrm{Mo}$ versus $\mathrm{Mo}+\mathrm{Bic}$ (effect of addition of sodium bicarbonate). 
Table 3. Ruminal distribution of VFA, $\mathrm{pH}$ values, and ammonia $\left(\mathrm{NH}_{3}-\mathrm{N}\right)$ concentration

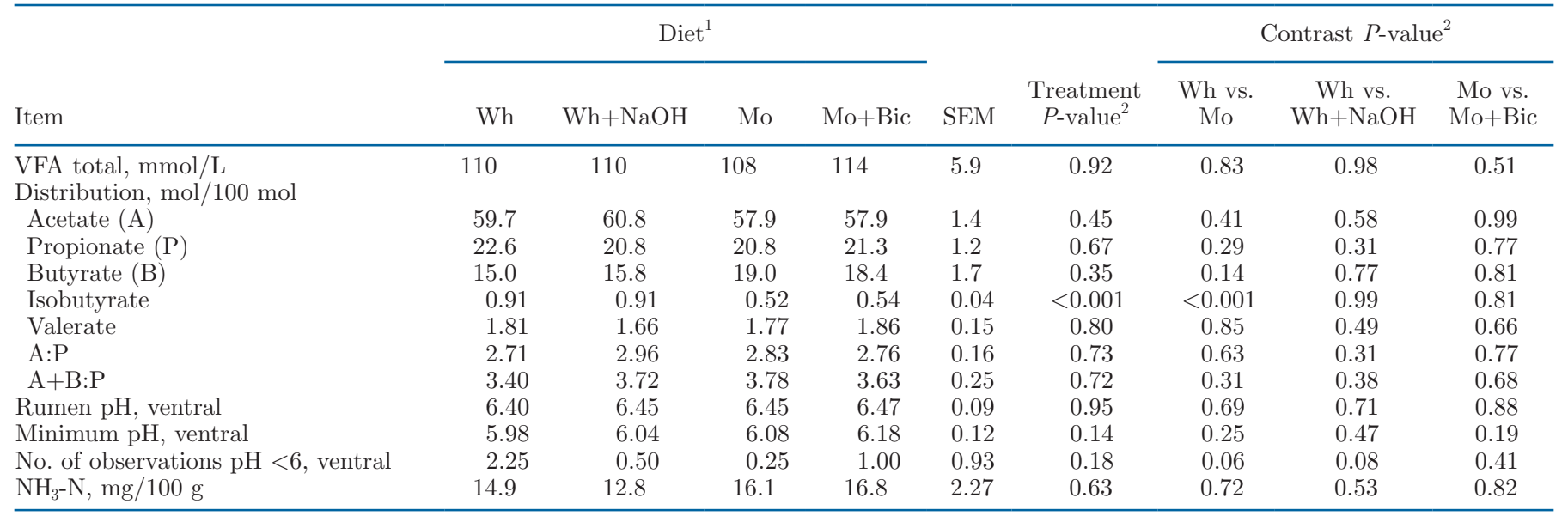

${ }^{1}$ The rations were based on late first-cut grass-clover silage supplemented with wheat (Wh), NaOH-treated wheat $(\mathrm{Wh}+\mathrm{NaOH})$, sugar beet molasses (Mo), or sugar beet molasses with addition of sodium bicarbonate (Mo+Bic).

${ }^{2} P$-values are given for the overall treatment effects and for orthogonal contrasts for Wh versus Mo (effect of carbohydrate source), Wh versus $\mathrm{Wh}+\mathrm{NaOH}$ (effect of $\mathrm{NaOH}$ treatment), and Mo versus Mo+Bic (effect of addition of sodium bicarbonate).

but it was affected by sampling time $(P<0.001)$, and there was an interaction between treatment and time $(P<0.03)$.

\section{Rumen Microbial Synthesis and Turnover}

There were no effects of diet on the microbial synthesis of DM and protein and no effects on efficiency of the microbial protein synthesis. Rumen evacuation data showed a difference in some of the rumen pool characteristics between the Wh and Mo diets. The pool of free fluid was significantly higher $(P=0.04)$ for the Mo diet $(14.9 \mathrm{~kg})$ than for the Wh diet $(11.9 \mathrm{~kg})$. In accordance with this, the content of DM in the rumen pool was lower for the Mo diet $(117 \mathrm{~g} / \mathrm{kg})$ than for the Wh diet $(124 \mathrm{~g} / \mathrm{kg})$. However, the total rumen pool $(\mathrm{kg})$ was unaffected by diet. There was a tendency toward a higher free fluid pool when wheat was treated with $\mathrm{NaOH}(P=0.07)$ or when bicarbonate was added to the molasses diet $(P=0.10)$. Treatment of wheat with $\mathrm{NaOH}$ caused a higher DM concentration in the rumen pool (131 vs. $124 \mathrm{~g} / \mathrm{kg} ; P=0.04$ ) and a larger rumen protein pool $(2.04$ vs. $1.82 \mathrm{~kg} ; P=0.01)$. For the 3 pools of NDF (Table 4), there were no significant effects of $\mathrm{CHO}$ source, $\mathrm{NaOH}$ treatment, or addition of bicarbonate.

There was a tendency $(P=0.09)$ toward higher passage rate of iNDF due to $\mathrm{NaOH}$ treatment of wheat $(2.63 \%$ vs. $2.37 \% / \mathrm{h})$, whereas there was no difference between Wh and Mo diets in this regard. The degradation rate of dNDF was not significantly affected by $\mathrm{CHO}$ source, $\mathrm{NaOH}$ treatment, or addition of bicarbonate.

\section{Methane Production}

Dry matter intake during the $4 \mathrm{~d}$ of $\mathrm{CH}_{4}$ measurements in the metabolism chambers (Table 5) was not different $(P=0.49$, Student's $t$-test) from DMI during the period of digesta sampling (Table 2). However, the lower intake for the Wh diet compared with the other 3 diets was less pronounced during $\mathrm{CH}_{4}$ measurements than during digesta sampling.

Replacing wheat with molasses consistently increased methane production irrespective of the unit for expression of $\mathrm{CH}_{4}$ production and increased the production of $\mathrm{H}_{2}$ from only 5.8 for the Wh diet to $27.1 \mathrm{~L} / \mathrm{d}$ for the Mo diet $(P<0.001)$.

Treatment of wheat with $\mathrm{NaOH}$ increased the production of $\mathrm{CH}_{4}$ from 547 to $640 \mathrm{~L} / \mathrm{d}(P=0.04)$ and from 0.091 to $0.101 \mathrm{~L}$ of $\mathrm{CH}_{4} / \mathrm{L}$ of $\mathrm{CO}_{2}(P=0.04)$. However, when $\mathrm{CH}_{4}$ production was related to DMI or kilograms of ECM, it was not significantly affected by the $\mathrm{NaOH}$ treatment. Production of $\mathrm{CH}_{4}$ per kilogram of true digested $\mathrm{OM}$ in the rumen was numerically higher for the $\mathrm{Wh}+\mathrm{NaOH}$ diet than for the Wh diet $(P=0.12)$. There was no effect of bicarbonate addition to the molasses diet regardless of whether the $\mathrm{CH}_{4}$ production was expressed as liters per day or related to feed intake, digested OM, or milk yield.

Methane production for the Wh diet was significantly lower than for the Mo diet during 1400 to 1700 $\mathrm{h}$, which was 7 to $10 \mathrm{~h}$ after the morning feeding at 0630 (Figure 2). Likewise, the Wh diet gave less $\mathrm{CH}_{4}$ production from 2300 to $0200 \mathrm{~h}$, which was 6 to $9 \mathrm{~h}$ after the afternoon feeding at $1630 \mathrm{~h}$. Hence, the lower diurnal $\mathrm{CH}_{4}$ production on the Wh diet was mainly due 
to these periods, whereas the difference in $\mathrm{CH}_{4}$ production between the 2 diets was much smaller in the first hours after feeding and in the hours before the morning feeding.

\section{Milk Production}

The Wh diet led to a higher production of milk $(22.2$ vs. $19.3 \mathrm{~kg} / \mathrm{d} ; P=0.03)$ and ECM (23.7 vs. $22.1 \mathrm{~kg} / \mathrm{d}$; $P=0.08$ ) than the Mo diet (Table 6). Treatment of wheat with $\mathrm{NaOH}$ increased the ECM production by approximately $3 \mathrm{~kg} / \mathrm{d}(P=0.01)$. The concentration of fat (48.1 vs. $44.4 \mathrm{~g} / \mathrm{kg} ; P=0.06$ ) and protein (41.5 vs. $39.9 \mathrm{~g} / \mathrm{kg} ; P=0.02)$ was higher in the Mo diet than in the Wh diet, whereas lactose was significantly lower in the Mo diet than in the Wh diet (46.1 vs. $47.0 ; P=$ $0.05)$. There was no effect of bicarbonate supplementa- tion of the molasses diet on milk yield, ECM yield, or content of fat, protein, or lactose.

\section{DISCUSSION}

\section{Carbohydrate Source}

Methane Production. Methane production per day and per kilogram of DMI was high in the present experiment compared with earlier studies (Brask et al., 2013a,b), where cows usually produced less than $600 \mathrm{~L}$ of $\mathrm{CH}_{4} / \mathrm{d}$ and less than $30 \mathrm{~L} / \mathrm{kg}$ of DMI. This may be related to the rather mature grass silage used in this study, as we have previously shown (Brask et al., 2013a) that cows eating more mature grass silage also produce more $\mathrm{CH}_{4}$. The lower daily $\mathrm{CH}_{4}$ production $(\mathrm{L} / \mathrm{d})$ for the Wh diet compared with the Mo diet could partly be

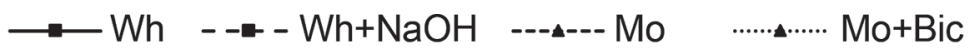

A

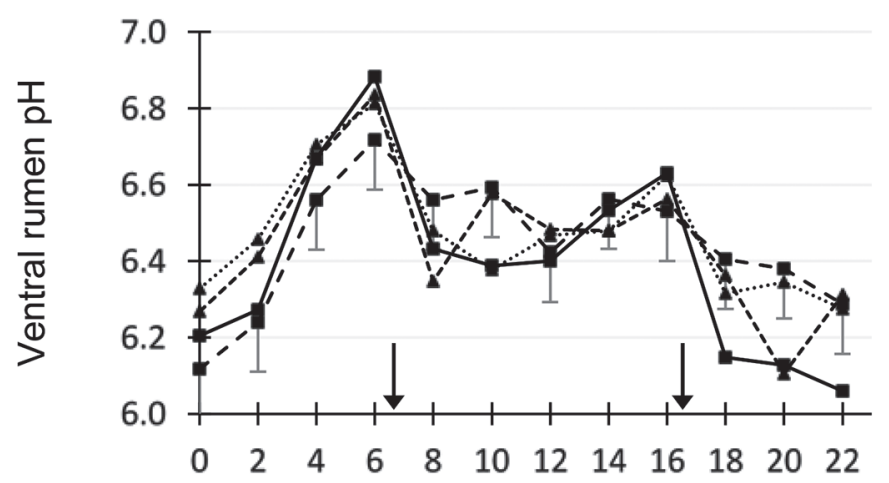

$\mathrm{C}$

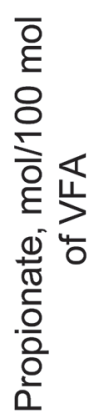

B

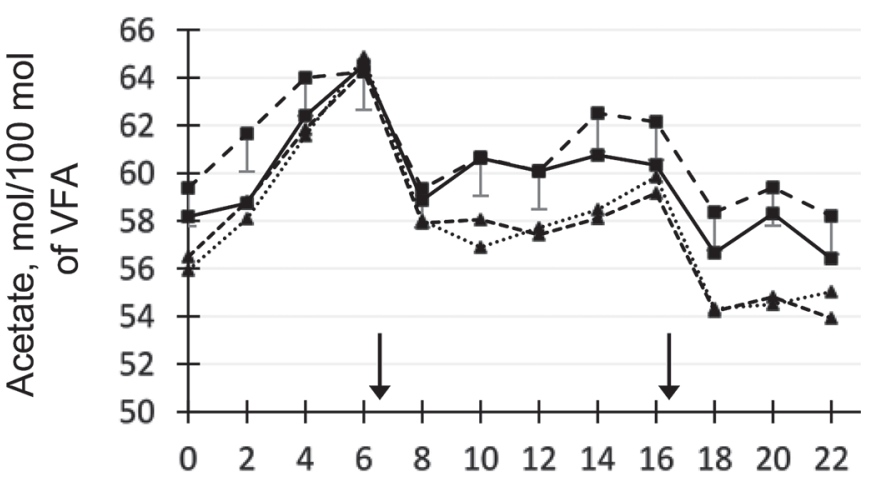

D

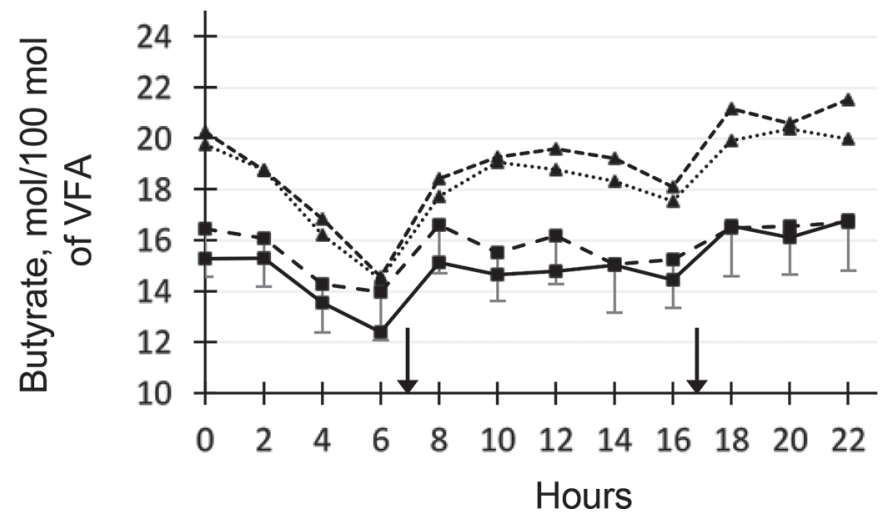

Figure 1. Diurnal pH profile in the ventral rumen (A), acetate proportion of total VFA (B), propionate proportion of total VFA (C), and butyrate proportion of total VFA (D). Arrows indicate feeding times (0630 and $1630 \mathrm{~h}$ ). The rations were based on late first-cut grass-clover

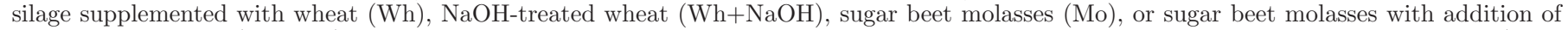

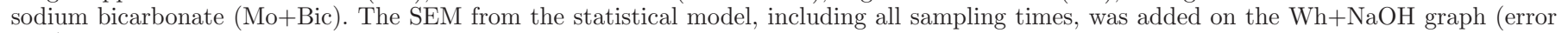
bars) and was $0.13,1.6,1.3$, and 1.9 units for panels A, B, C, and D, respectively. 
Table 4. Microbial synthesis, microbial efficiency, rumen pool sizes, rumen passage rate of indigestible NDF (iNDF), and degradation rate of digestible NDF (dNDF)

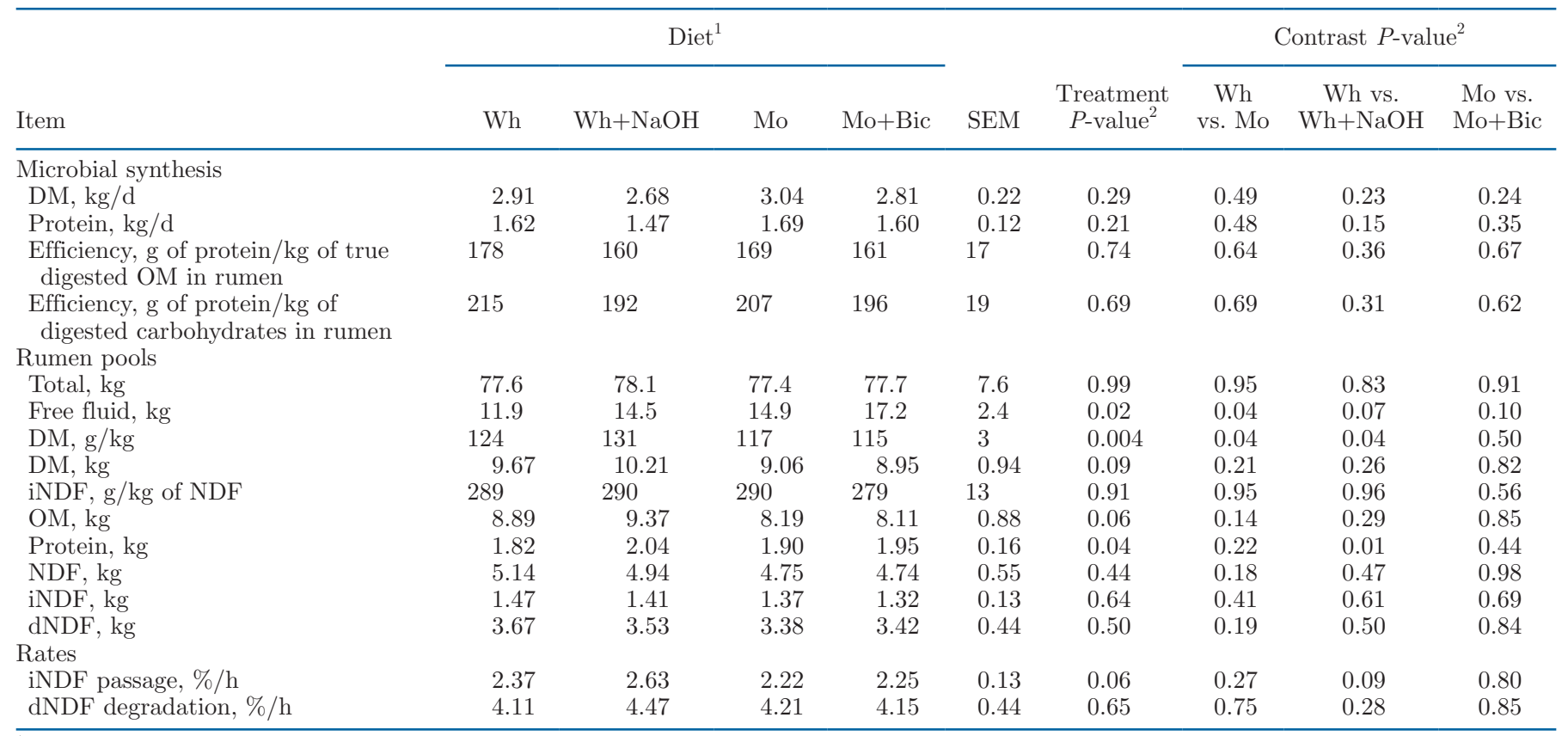

${ }^{1}$ The rations were based on late first-cut grass-clover silage supplemented with wheat $(\mathrm{Wh}), \mathrm{NaOH}$-treated wheat $(\mathrm{Wh}+\mathrm{NaOH})$, sugar beet molasses (Mo), or sugar beet molasses with addition of sodium bicarbonate (Mo+Bic).

${ }^{2} P$-values are given for the overall treatment effects and for orthogonal contrasts for Wh versus Mo (effect of carbohydrate source), Wh versus $\mathrm{Wh}+\mathrm{NaOH}$ (effect of $\mathrm{NaOH}$ treatment), and Mo versus Mo+Bic (effect of addition of sodium bicarbonate)

explained with lower feed intake. The higher intake of the Mo diet could be expected due to increased palatability when molasses is added to the diet (Primdal et al., 2014). However, also $\mathrm{CH}_{4}$ per kilogram of DMI differed between Wh and Mo diets. When $\mathrm{CH}_{4}$ production was related to the amount of true digested OM in the rumen, the numerical difference was rather high, with a $\mathrm{CH}_{4}$ production of $65.3 \mathrm{~L} / \mathrm{kg}$ of true rumen-digested OM for the Mo diet versus only $58.5 \mathrm{~L} / \mathrm{kg}$ of true rumen-digested $\mathrm{OM}$ for the Wh diet. This indicates that $\mathrm{CH}_{4}$ production per kilogram of true digested $\mathrm{OM}$ in the rumen in diets with molasses is higher than that

Table 5. Methane and hydrogen production

\begin{tabular}{|c|c|c|c|c|c|c|c|c|c|}
\hline \multirow[b]{2}{*}{ Item } & \multicolumn{4}{|c|}{ Diet $^{1}$} & \multirow[b]{2}{*}{ SEM } & \multirow[b]{2}{*}{$\begin{array}{c}\text { Treatment } \\
P \text {-value }\end{array}$} & \multicolumn{3}{|c|}{ Contrast $P$-value ${ }^{2}$} \\
\hline & Wh & $\mathrm{Wh}+\mathrm{NaOH}$ & Mo & $\mathrm{Mo}+\mathrm{Bic}$ & & & $\begin{array}{c}\text { Wh vs. } \\
\text { Mo }\end{array}$ & $\begin{array}{c}\text { Wh vs. } \\
\text { Wh+NaOH }\end{array}$ & $\begin{array}{l}\text { Mo vs. } \\
\text { Mo+Bic }\end{array}$ \\
\hline DMI, $\mathrm{kg} / \mathrm{d}$ & 16.9 & 18.4 & 18.5 & 18.2 & 0.9 & 0.26 & 0.09 & 0.11 & 0.73 \\
\hline $\mathrm{CH}_{4}, \mathrm{~L} / \mathrm{d}$ & 547 & 616 & 671 & 640 & 36 & 0.02 & 0.004 & 0.04 & 0.30 \\
\hline $\mathrm{CH}_{4}, \mathrm{~L} / \mathrm{kg}$ of $\mathrm{DMI}$ & 32.5 & 33.6 & 36.2 & 35.1 & 1.4 & 0.16 & 0.05 & 0.51 & 0.48 \\
\hline $\mathrm{CH}_{4}, \mathrm{~L} / \mathrm{kg}$ of $\mathrm{ECM}$ & 24.4 & 24.3 & 31.5 & 29.3 & 1.6 & 0.01 & 0.003 & 0.96 & 0.20 \\
\hline $\mathrm{CH}_{4}, \mathrm{~L} / \mathrm{kg}$ of total digested $\mathrm{OM}$ & 45.9 & 47.7 & 52.7 & 51.8 & 1.7 & 0.02 & 0.01 & 0.33 & 0.60 \\
\hline $\mathrm{CH}_{4}, \%$ of $\mathrm{GEI}^{4}$ & 7.10 & 7.39 & 8.24 & 8.03 & 0.30 & 0.04 & 0.01 & 0.41 & 0.53 \\
\hline $\mathrm{CH}_{4}: \mathrm{CO}_{2}, \mathrm{~L} / \mathrm{L}$ & 0.091 & 0.101 & 0.112 & 0.108 & 0.004 & 0.01 & 0.001 & 0.04 & 0.36 \\
\hline $\mathrm{H}_{2}, \mathrm{~L} / \mathrm{d}$ & 5.8 & 4.7 & 27.1 & 27.3 & 3.7 & 0.001 & 0.001 & 0.76 & 0.96 \\
\hline
\end{tabular}

${ }^{1}$ The rations were based on late first-cut grass-clover silage supplemented with wheat (Wh), NaOH-treated wheat $(\mathrm{Wh}+\mathrm{NaOH})$, sugar beet molasses (Mo), or sugar beet molasses with addition of sodium bicarbonate (Mo+Bic).

${ }^{2} P$-values are given for the overall treatment effects and for orthogonal contrasts for Wh versus Mo (effect of carbohydrate source), Wh versus Wh $+\mathrm{NaOH}$ (effect of $\mathrm{NaOH}$ treatment), and Mo versus Mo+Bic (effect of addition of sodium bicarbonate).

${ }^{3}$ True OM digestibility determined for each cow and diet in the previous week was used together with the actual OM intake in the respiration chambers to calculate kilograms of true digested $\mathrm{OM}$ in the rumen.

${ }^{4} \mathrm{GEI}=$ gross energy intake $(\mathrm{kg} / \mathrm{d})$. 
Table 6. Milk production measured during the $4 \mathrm{~d}$ in the respiration chambers

\begin{tabular}{|c|c|c|c|c|c|c|c|c|c|}
\hline Item & \multicolumn{4}{|c|}{$\operatorname{Diet}^{1}$} & SEM & $\begin{array}{c}\text { Treatment } \\
P \text {-value }\end{array}$ & \multicolumn{3}{|c|}{ Contrast $P$-value ${ }^{2}$} \\
\hline $\mathrm{ECM}, \mathrm{kg} / \mathrm{d}$ & 23.7 & 26.5 & 22.1 & 22.0 & 2.2 & 0.004 & 0.08 & 0.01 & 0.91 \\
\hline Fat, $\mathrm{g} / \mathrm{kg}$ of milk & 44.4 & 44.9 & 48.1 & 46.5 & 3.1 & 0.20 & 0.06 & 0.75 & 0.37 \\
\hline Protein, $\mathrm{g} / \mathrm{kg}$ of milk & 39.9 & 40.2 & 41.5 & 41.9 & 1.8 & 0.02 & 0.02 & 0.53 & 0.54 \\
\hline
\end{tabular}

${ }^{1}$ The rations were based on late first-cut grass-clover silage supplemented with wheat $(\mathrm{Wh})$, NaOH-treated wheat $(\mathrm{Wh}+\mathrm{NaOH})$, sugar beet molasses (Mo), or sugar beet molasses with addition of sodium bicarbonate (Mo+Bic).

${ }^{2} P$-values are given for the overall treatment effects and for orthogonal contrasts for Wh versus Mo (effect of carbohydrate source), Wh versus $\mathrm{Wh}+\mathrm{NaOH}$ (effect of $\mathrm{NaOH}$ treatment), and $\mathrm{Mo}$ versus $\mathrm{Mo}+\mathrm{Bic}$ (effect of addition of sodium bicarbonate).

in diets with wheat. This is in accordance with results from Hatew et al. (2015), who found a decrease in both daily $\mathrm{CH}_{4}$ production and $\mathrm{CH}_{4}$ production per kilogram of rumen-fermentable $\mathrm{OM}$ when the starch level was increased from $11.5 \%$ to $21.2 \%$ in the diet. They also found that replacing native corn grain with more rapid fermentable gelatinized corn grain further decreased the $\mathrm{CH}_{4}$ production per kilogram of rumen-fermentable OM. The reducing effect on the $\mathrm{CH}_{4}$ production of both more starch and making the starch more rapidly fermentable occurred even if there were no differences in the rumen $\mathrm{pH}$ or proportion of butyric acid proportion during the first $8 \mathrm{~h}$ after feeding, and there was only a slight increase in the proportion of propionic acid due to the gelatinized grain.

The loss of gross energy as $\mathrm{CH}_{4}$ was $8.2 \%$ for the Mo diet, which was significantly more than the $7.1 \%$ on the wheat diet. Kirchgessner et al. (1994) found an increase in the proportion of $\mathrm{GE}$ intake lost as $\mathrm{CH}_{4}$ from $6.1 \%$ to $6.8 \%$ when $6.5 \mathrm{~kg}$ of DM from a starch-rich concentrate was replaced with $4.5 \mathrm{~kg}$ of DM from sucrose and $1.7 \mathrm{~kg}$ of DM from soybean meal. Müller et al. (1994) reported

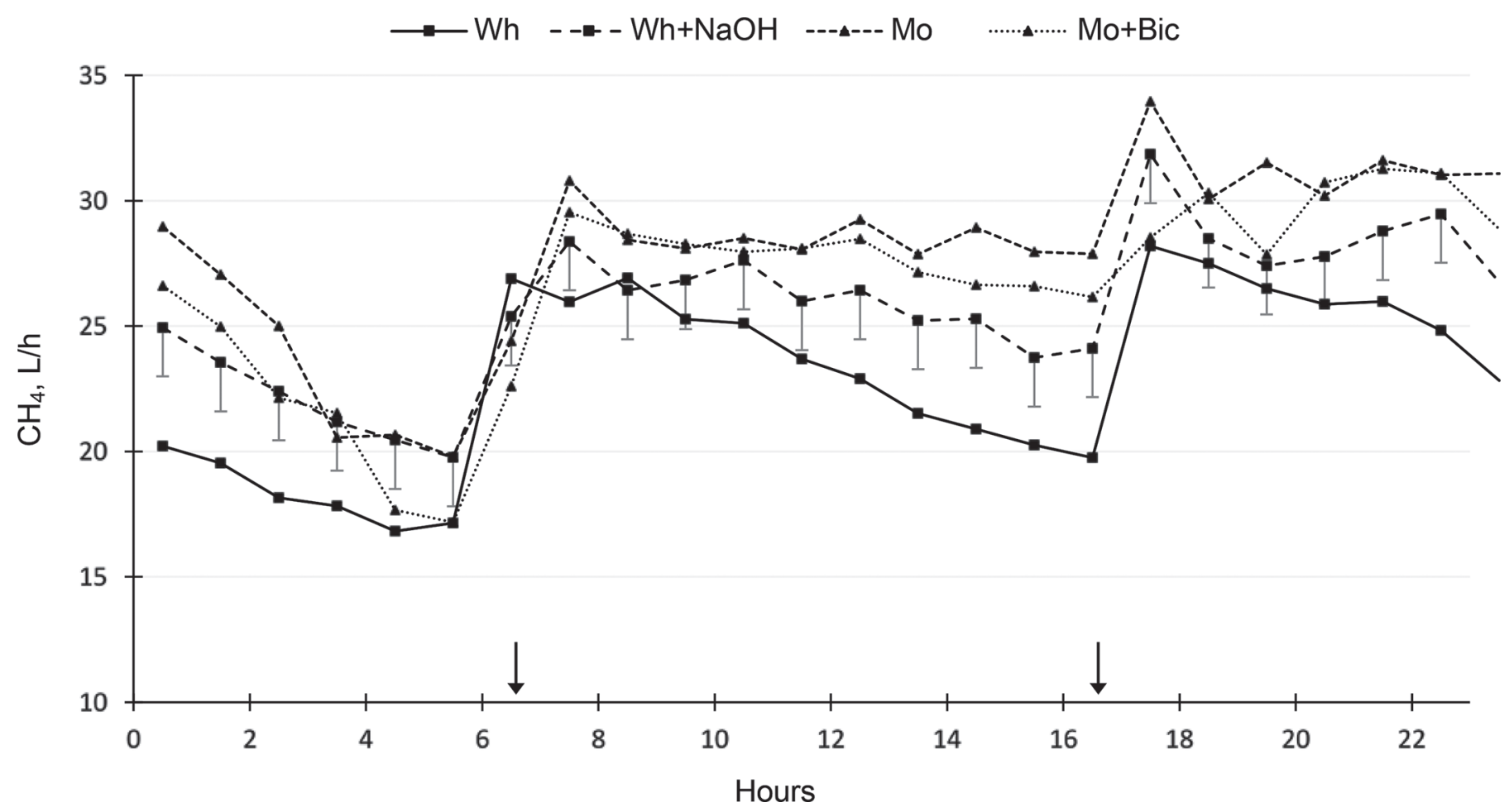

Figure 2. Diurnal methane $\left(\mathrm{CH}_{4}\right)$ production. Arrows indicate feeding times $(0630$ and $1630 \mathrm{~h})$. The rations were based on late first-cut grass-clover silage supplemented with wheat (Wh), $\mathrm{NaOH}$-treated wheat (Wh+NaOH), sugar beet molasses (Mo), or sugar beet molasses with addition of sodium bicarbonate (Mo+Bic). Error bars show SEM (1.95). 
an increase in the proportion of GE intake lost as $\mathrm{CH}_{4}$ from $6.2 \%$ to $7.2 \%$ when $7.5 \mathrm{~kg}$ of $\mathrm{DM}$ from fodder beets and $2.0 \mathrm{~kg}$ of DM from soybean meal replaced 5.8 $\mathrm{kg}$ of DM from a starch-rich concentrate and $4.6 \mathrm{~kg}$ of DM from grass silage.

The higher $\mathrm{CH}_{4}$ production per kilogram of DMI on the Mo diet than on the Wh diet is also in line with the findings of Murphy et al. (1982) as well as Hindrichsen and Kreuzer (2009), who found a higher $\mathrm{CH}_{4}$ production from sugar than from starch in an in vitro system. However, in an in vivo experiment with dairy cows, a diet with molasses did not result in more enteric $\mathrm{CH}_{4}$ than a diet with wheat (Hindrichsen et al., 2005). However, in that study, sugar replaced only $60 \%$ of the amount of starch omitted, whereas in the present study $213 \mathrm{~g}$ of starch was replaced by an equal amount of sugar (i.e., $207 \mathrm{~g}$ ).

On the molasses diet, $27 \mathrm{~L}$ of $\mathrm{H}_{2} / \mathrm{d}$ escaped the rumen, whereas only $5 \mathrm{~L}$ of $\mathrm{H}_{2} / \mathrm{d}$ was emitted on the wheat diet. Peak emission of hydrogen was observed just after feeding.

During both day and night, the butyric acid proportion of VFA in the rumen was higher for the Mo diet than for the Wh diet (Figure 1D), and this pattern coincided with the diurnal pattern of methane (Figure 2 ). The diurnal mean proportion of butyric acid was 19.0 versus 15.0 for the Mo and Wh diets, respectively. The diurnal mean proportion of propionate was 20.8 for the Mo diet versus 22.6 for the Wh diet. According to stoichiometry (Ungerfeld and Kohn, 2006), ruminal fermentation of $1 \mathrm{~mol}$ of glucose can yield $1 \mathrm{~mol}$ of butyrate and $2 \mathrm{~mol}$ of $\mathrm{H}_{2}$ or alternatively yield $2 \mathrm{~mol}$ of propionate while utilizing $2 \mathrm{~mol}$ of $\mathrm{H}_{2}$. Most $\mathrm{H}_{2}$ is used for methane production, when $4 \mathrm{~mol}$ of $\mathrm{H}_{2}$ reacts with $1 \mathrm{~mol}$ of $\mathrm{CO}_{2}$ to form $1 \mathrm{~mol}$ of $\mathrm{CH}_{4}$ and $2 \mathrm{~mol}$ of $\mathrm{H}_{2} \mathrm{O}$. Despite the lack of significance between the diets regarding average diurnal butyrate and propionate proportion in the rumen, the joint changes of butyrate and propionate are probably the reason for the effect on $\mathrm{H}_{2}$ and methane.

Contrarily, Hindrichsen and Kreuzer (2009) did not find differences in emitted hydrogen between sugar and starch diets in vitro. Pinares-Patiño et al. (2011) found higher emissions of hydrogen when sheep were fed concentrate instead of grass, indicating that hydrogen production in some situations may exceed the utilization capacity of the rumen methanogens.

Rumen Metabolism. For the 2 molasses diets, low rumen digestibility of starch was found. Larsen et al. (2009) reported microbial polysaccharide synthesis in the rumen, especially in diets rich in starch or sugar. Microbial polysaccharides analyzed as starch could explain the low rumen starch digestibility in diets with molasses in the present trial, as starch intake (0.25 and
$0.21 \mathrm{~kg} / \mathrm{d}$ for Mo and Mo+Bic, respectively) was very low. No sugar analyses were made in digesta and feces because previous work has shown that sugars are rapidly fermented in the rumen with a degradation rate of 400 to $700 \% / \mathrm{h}$ and, therefore, none of the sugar in feed can be found in duodenal or fecal material (Weisbjerg et al., 1998). Rumen NDF digestibility is often reduced in diets with a high starch content. Khalili and Huhtanen (1991) reported that the depression of fiber digestion can be divided into an effect of the $\mathrm{CHO}$ per se and the decrease in rumen $\mathrm{pH}$ due to rapidly fermentable CHO. However, these effects are difficult to distinguish. Hatew et al. (2015) found no effect on NDF total-tract digestibility of either level of starch (212 vs. $115 \mathrm{~g} / \mathrm{kg}$ of $\mathrm{DM})$ or fermentation rate of the starch source $(5.5 \% / \mathrm{h}$ for native corn grain vs. $15.5 \% / \mathrm{h}$ for gelatinized corn grain). Surprisingly, there was no effect of starch source and no effect of amount of starch on rumen $\mathrm{pH}$ during the first $8 \mathrm{~h}$ after morning feeding, implying that the lack of effect on rumen NDF digestibility might be due to lack of effect on $\mathrm{pH}$.

Rumen NDF digestibility in the present study with diets based on late first-cut grass-clover silage was on average $67 \%$. This is in line with an earlier study where rumen NDF digestibility was $66 \%$ for diets based on late first-cut grass-clover silage and $70 \%$ for diets based on early first-cut grass silage, whereas it was only $51 \%$ for diets based on maize silage (Brask et al., 2013a). In the present experiment, there was no effect on rumen NDF digestibility of $\mathrm{CHO}$ source, and there were no significant differences between treatments on rumen $\mathrm{pH}$. In a study with a rumen fermenter with varying $\mathrm{pH}$ and varying levels of easily fermentable $\mathrm{CHO}$ (Weisbjerg et al., 1999), pH did not affect NDF digestibility. However, increasing amounts of starch decreased the NDF digestibility by 23 percentage units $(P=0.004)$, whereas similar increases in the amount of molasses decreased the NDF digestibility by only 13 percentage units $(P=0.1)$. This indicates that the negative effect of easily digestible $\mathrm{CHO}$ on NDF degradation is due to an effect of substrate more than to an effect of $\mathrm{pH}$.

In the present experiment, there was no significant effect of the CHO source on iNDF passage rate. Stensig et al. (1998) found a higher passage rate of iNDF in diets with 20 to $30 \%$ sucrose in DM compared with diets with 20 to $30 \%$ wheat flour. They also found a lower rate of degradation of NDF for sucrose diets, and they measured a decreased rate of degradation of NDF for $30 \%$ inclusion compared with $20 \%$ inclusion for both sources of CHO. In combination, this led to a lower total-tract digestibility of NDF when high amounts of sucrose were fed. This is contradictory to the present experiment, where the total-tract digestibility of NDF was lowest for the Wh diet due to a slightly higher rate 
of passage of iNDF and a slightly lower degradation rate of dNDF compared with the Mo diet. One possible explanation for the different effects of sugar and starch found in the present study compared with the study of Stensig et al. (1998) could be the sources of sugar and starch. The wheat flour and the sucrose used by Stensig et al. (1998) may have been more readily available in the rumen than starch from wheat and sugar from molasses in the present experiment. Stensig et al. (1998) used early-lactation cows, which may have been more vulnerable to high amounts of readily available CHO than the mid-lactation cows in the present study.

The duodenal material is heterogeneous, and therefore the standard error of the mean value of the rumen digestibility of NDF was higher: 3.0 units compared with only 1.2 units for total-tract NDF digestibility. This means that the difference of 3.3 units found between Wh and Mo in the total-tract digestibility is probably a real difference, whereas the lack of difference in rumen digestibility may be due to the larger variation. A biological reason to believe that the lower total-tract NDF digestibility in the Wh diet is in fact real is that in the Wh diet, $16 \%$ of the dietary NDF came from wheat, whereas all NDF came from grass-clover silage in the Mo diet because NDF from wheat kernels is less digestible $(3.5 \% / \mathrm{h})$ than NDF from grass-clover silage (4-5\%/h; Norfor, 2019).

Compared with the Wh diet, the Mo diet increased diurnal water intake and water intake per kilogram of $\mathrm{DM}$ (4.06 $\mathrm{kg}$ of water $/ \mathrm{kg}$ of $\mathrm{DM}$ for the Wh diet vs. $4.44 \mathrm{~kg}$ for the Mo diet; $P<0.001$ ), which may be due to the osmotic effect of a high content of cations in the Mo diet (Araba et al., 2002). In theory, the higher water intake would dilute the rumen fluid and increase liquid outflow from the rumen. This would be seen as a lower total VFA concentration and a higher rumen $\mathrm{pH}$. In line with this, there were more observations with $\mathrm{pH}$ below 6.0 and lower water intake in the Wh diet, which was also in agreement with earlier studies (Owens et al., 2008; Ramin and Huhtanen, 2013).

Rumen fermentation of sugar from molasses increased the butyrate proportion compared with the Wh diet at all sampling times, and for 8 of the 12 sampling times butyrate tended to be significantly higher for the Mo diet $(P<0.10)$. Higher butyrate proportions for the Mo diet were most evident after feeding, which illustrates that sugar is quickly fermented. Vallimont et al. (2004) reported no significant difference between starch and sucrose in the daily average VFA pattern but found more butyrate with sucrose feeding in the first $5 \mathrm{~h}$ postfeeding in an in vitro system, indicating rapid degradation of sugar. Stensig et al. (1998) found that the mean diurnal butyrate proportion was 2.6 percentage units higher with $20 \%$ of DM from sucrose compared with $20 \%$ from pure wheat starch. When the $30 \%$ sucrose and $30 \%$ pure wheat starch were compared, the butyrate proportion was 5.3 percentage units higher for the sucrose diet in accordance with the 4 percentage units higher butyrate for the Mo diet than for the Wh diet in the present experiment. Dijkstra et al. (2012) reported that butyrate is absorbed faster than other VFA and that increased production of butyrate due to sugar feeding is not necessarily fully reflected in the measured butyrate concentrations in the rumen.

The larger pool of free fluid for the Mo diet than the Wh diet and the lower concentration of DM in the rumen pool for the Mo diet indicate that there were more osmotically active products in the rumen of Mo-fed cows during rumen evacuation approximately $5 \mathrm{~h}$ after feeding than in the Wh-fed cows. Also, water intake was higher for the Mo diet than for the Wh diet.

\section{$\mathrm{NaOH}$ Treatment of Wheat}

The amount of OM fermented in the rumen is the most important driver for the production of $\mathrm{CH}_{4}$ (Brask et al., 2015). Rumen digestibility of starch was lower for the diet with $\mathrm{NaOH}$-treated wheat compared with rolled wheat in agreement with earlier findings (Phipps et al., 2001; Larsen et al., 2009). Despite the lower starch digestibility of $69.7 \%$ for $\mathrm{NaOH}$-treated wheat versus $87.8 \%$ for the rolled wheat, the difference in the amount of starch digested in the rumen was only $0.46 \mathrm{~kg} / \mathrm{d}$ between rolled wheat and $\mathrm{NaOH}-$ treated wheat due to a higher feed intake in the diet with treated wheat. This may have counteracted the expected effect of the $\mathrm{NaOH}$ treatment of wheat on the rumen fermentation pattern, and therefore no effect on the production of $\mathrm{CH}_{4}$ per kilogram of DMI could be expected.

The inclusion of $3 \mathrm{~kg}$ of $\mathrm{NaOH} / 100 \mathrm{~kg}$ of wheat was based on findings by Mortensen et al. (1993) to obtain a significant decrease in starch degradation in the rumen without supplying extreme amounts of $\mathrm{NaOH}$. Furthermore, Hymøller et al. (2014) showed a total-tract starch digestibility of $99.2 \%$ of wheat kernels treated with 3 $\mathrm{kg}$ of $\mathrm{NaOH} / 100 \mathrm{~kg}$ of wheat. When $\mathrm{NaOH}$ reacts with wheat kernels, only a limited amount of $\mathrm{OH}$ ions are left in the product because a surplus will react with atmospheric $\mathrm{CO}_{2}$ to form water and $\mathrm{Na}_{2} \mathrm{CO}_{3}$. Therefore, $\mathrm{NaOH}$ cannot be expected to have a direct $\mathrm{pH}$ effect in the rumen but only an indirect effect due to $\mathrm{Na}_{2} \mathrm{CO}_{3}$ and to the lower rumen digestibility of starch. When no direct effect of $\mathrm{NaOH}$ can be expected on $\mathrm{pH}$, no effect on NDF digestibility can be expected. As discussed elsewhere, the extra dietary $\mathrm{Na}$ can be the reason for 
the higher water intake due to the $\mathrm{NaOH}$ treatment of wheat. In fact, the $\mathrm{NaOH}$ treatment in the present trial did not significantly affect the average rumen $\mathrm{pH}$ in the medial or ventral rumen compared with the rolled wheat kernels, which is in agreement with the findings of Phipps et al. (2001).

Apparently, rumen $\mathrm{pH}$ was affected only by $\mathrm{NaOH}$ treatment or bicarbonate supplementation shortly after feeding. In general, rumen $\mathrm{pH}$ did not reach a critical level at any point of time in this trial. In this trial, 13 out of 16 observations with $\mathrm{pH}<6$ were from 1 multiparous early-lactation cow, which compared with the 3 primiparous cows had a higher milk yield and feed intake, which might indicate a larger effect of $\mathrm{NaOH}$ treatment and of bicarbonate supplementation in cows with higher yield and higher feed intake.

In the present experiment, feed intake tended to be lower for the $\mathrm{Wh}$ diet than for the $\mathrm{Wh}+\mathrm{NaOH}$ diet. The lower rumen starch digestibility of $\mathrm{NaOH}$-treated wheat might have increased feed intake and, therefore, passage rate as indicated by the tendency to the increased iNDF passage rate.

No effect of $\mathrm{NaOH}$ treatment of wheat was found on the rumen fermentation pattern by O'Mara et al. (1997). Khalili and Huhtanen (1991) concluded that the depression in fiber digestion with sugar feeding is mainly due to a decreased $\mathrm{pH}$, as the negative effect of sugar is alleviated by feeding sodium bicarbonate. There was no significant increase in the rumen NDF digestibility in the present trial when wheat was treated with $\mathrm{NaOH}$ treated or when the molasses diet was supplemented with bicarbonate. The lack of effect on NDF digestibility can probably be explained by the high rumen $\mathrm{pH}$, as $\mathrm{pH}$ did not reach a critically low level for fiber digestion, which is between 6.0 and 6.3 (Dijkstra et al., 2012). In fact, only 1 cow had a few samplings with a pH below 6.0.

Stensig et al. (1998) found that the mean diurnal acetate proportion was $60.1 \%$ and the propionate proportion was $22.3 \%$ in cows fed $20 \%$ of DM from wheat starch compared with $55.9 \%$ acetate and $26.6 \%$ propionate when $30 \%$ of the DM was from pure wheat starch. Similarly, they found a diurnal acetate proportion of $57.4 \%$ and a propionate proportion of $22.9 \%$ in cows fed $20 \%$ of DM from sucrose compared with $53.9 \%$ acetate and $24.5 \%$ propionate when $30 \%$ of the DM was from sucrose.

This means that the level of starch and sugar is very important for the rumen VFA distribution. Hence, the level of approximately $25 \%$ starch and sugar in the $\mathrm{Wh}$ and Mo diets, respectively, in the present study was probably not high enough to cause negative effects on the rumen $\mathrm{pH}$, the rumen VFA distribution, or the rumen NDF digestibility. Therefore, no clear effects of
$\mathrm{NaOH}$ treatment of wheat or bicarbonate supplementation to the molasses diet could be expected.

In accordance with our findings, Bougouin et al. (2018) found no effect on apparent total-tract NDF digestibility when bicarbonate was added to a starch-rich $\operatorname{diet}(231 \mathrm{~g} / \mathrm{kg}$ of DM) despite the fact that they found a significant increase in both mean and minimum $\mathrm{pH}$ in the rumen. This indicates that lower $\mathrm{pH}$ is not per se the major reason if NDF digestibility is negatively affected by increased dietary concentration of fermentable $\mathrm{CHO}$.

The higher DM concentration in the rumen pool for the $\mathrm{Wh}+\mathrm{NaOH}$ diet could be due to more intact starch and less osmotically active starch degradation products in this diet compared with the Wh diet because the $\mathrm{NaOH}$ treatment of wheat reduced the rumen degradation of starch from $88 \%$ to $70 \%$. The higher amount of free fluid in the $\mathrm{Wh}+\mathrm{NaOH}$ and $\mathrm{Mo}+\mathrm{Bic}$ diets could be due to the osmotic effect of the higher intake of $\mathrm{Na}$ in these 2 diets followed by a higher water uptake. There were no effects of $\mathrm{NaOH}$ treatment on microbial protein efficiency ( $\mathrm{g}$ of protein $/ \mathrm{kg}$ of rumen-digested $\mathrm{CHO}$ ), which means that the amount of rumen fluid did not influence the microbial protein efficiency.

\section{Bicarbonate Supplementation}

Surprisingly, bicarbonate supplementation of the molasses diet affected neither the average nor the minimum $\mathrm{pH}$ in the ventral rumen. As discussed above, the lack of effect on $\mathrm{pH}$ could probably be ascribed to the fact that the sugar level was not high enough to cause adverse effects on the $\mathrm{pH}$ or VFA distribution in the rumen. Furthermore, the lack of effect of bicarbonate on $\mathrm{CH}_{4}$ emission was probably due to the lack of effect on $\mathrm{pH}$ and NDF digestibility in the rumen. High NDF content in forage and relatively high forage:concentrate ratio resulted in $\mathrm{pH}$ values in the rumen that were far from critical $\mathrm{pH}$ levels. Therefore, an effect on fiber digestion and methanogenic bacteria could not be expected because NDF digestibility is unaffected above a critical $\mathrm{pH}$ level but gets seriously affected below this level (Huhtanen et al., 2006).

In the present experiment, none of the 2 molassesbased diets gave very low minimum $\mathrm{pH}$. The higher $\mathrm{CH}_{4}$ production for the molasses diet compared with the wheat diet supports Hindrichsen et al. (2005), who hypothesized that sucrose diets are more methanogenic than isoenergetic diets with starch at high $\mathrm{pH}$, whereas the difference at low $\mathrm{pH}$ is minimal. Hindrichsen and Kreuzer (2009) found that the increased $\mathrm{CH}_{4}$ production at high ruminal $\mathrm{pH}$ was due to an increase in fiber digestibility. However, rumen fiber digestibility was not different between the Wh and the Mo diets in the pres- 
ent trial; therefore, differences in fiber digestibility cannot explain the difference in $\mathrm{CH}_{4}$ production between the Wh and Mo diets.

\section{CONCLUSIONS}

Replacing wheat with molasses and thereby increasing the sugar:starch ratio in the diet increases the $\mathrm{CH}_{4}$ production per kilogram of DMI from dairy cows, presumably by increasing the proportion of butyrate in the rumen VFA. Treatment of wheat with $\mathrm{NaOH}$ did not influence the $\mathrm{CH}_{4}$ production per kilogram of DMI under the present conditions. When rumen $\mathrm{pH}$ does not reach a critical low value, there is no effect on $\mathrm{CH}_{4}$ production of bicarbonate supplementation to diets with molasses.

\section{ACKNOWLEDGMENTS}

The authors thank Torkild N. Jakobsen and the barn staff for their skillful assistance during the experiment and laboratory technicians for analyzing the samples (Department of Animal Science, Aarhus University, Tjele, Denmark). This study was funded by the Danish Milk Levy Fund (Aarhus, Denmark) and Aarhus University (Tjele, Denmark).

\section{REFERENCES}

Åkerlind, M., M. R. Weisbjerg, T. Eriksson, R. Thøgersen, P. Uden, B. L. Olafsson, O. M. Harstad, and H. Volden. 2011. Feed analysis and digestion methods. Pages 41-54 In Norfor-The Nordic Feed Evaluation System. EAAP publication no. 130. H. Volden, ed. Wageningen Academic Publishers, Wageningen, the Netherlands.

Araba, A., F. M. Byers, and F. Guessous. 2002. Patterns of rumen fermentation in bulls fed barley/molasses diets. Anim. Feed Sci. Technol. 97:53-64. https://doi.org/10.1016/S0377-8401(01)00357 -1 .

Beauchemin, K. A., M. Kreuzer, F. O'Mara, and T. A. McAllister. 2008. Nutritional management for enteric methane abatement: A review. Aust. J. Exp. Agric. 48:21-27. https://doi.org/10.1071/ EA07199.

Boadi, D., C. Benchar, J. Chiquette, and D. Massé. 2004. Mitigation strategies to reduce enteric methane emissions from dairy cows: Update review. Can. J. Anim. Sci. 84:319-335. https://doi.org/10 .4141/A01-017.

Bougouin, A., A. Ferlay, M. Doreau, and C. Martin. 2018. Effects of carbohydrate type or bicarbonate addition to grass silage-based diets on enteric methane emissions and milk fatty acid composition in dairy cows. J. Dairy Sci. 101:6085-6097.

Brask, M., P. Lund, A. L. F. Hellwing, M. Poulsen, and M. R. Weisbjerg. 2013a. Enteric methane production, digestibility and rumen fermentation in dairy cows fed different forages with and without rapeseed fat supplementation. Anim. Feed Sci. Technol. 184:67-79. https://doi.org/10.1016/j.anifeedsci.2013.06.006.

Brask, M., P. Lund, M. R. Weisbjerg, A. L. F. Hellwing, M. Poulsen, M. K. Larsen, and T. Hvelplund. 2013b. Methane production and digestion of different physiological forms of rapeseed fat supplements in dairy cows. J. Dairy Sci. 96:2356-2365. https://doi.org/ 10.3168/jds.2011-5239.

Brask, M., M. R. Weisbjerg, A. L. F. Hellwing, A. Bannink, and P. Lund. 2015. Methane production and diurnal variation measured in dairy cows and predicted from fermentation pattern and nutrient or carbon flow. Animal 9:1795-1806. https://doi.org/10.1017/ S1751731115001184.

Brouwer, E. 1965. Report of Sub-committee on Constants and Factors: Energy metabolism. Pages 441-443 in Proc. 3rd Symposium, Troon, Scotland. Academic Press, Wageningen, the Netherlands.

Canibe, N., O. Højberg, J. H. Badsberg, and B. B. Jensen. 2007. Effect of feeding fermented liquid feed and fermented grain on gastrointestinal ecology and growth performance in piglets. J. Anim. Sci. 85:2959-2971. https://doi.org/10.2527/jas.2006-744.

Dijkstra, J., J. L. Ellis, E. Kebreab, A. B. Strathe, S. Lopez, J. France, and A. Bannink. 2012. Ruminal pH regulation and nutritional consequences of low pH. Anim. Feed Sci. Technol. 172:22-33. https:// doi.org/10.1016/j.anifeedsci.2011.12.005.

European Community. 2012. First commission directive 71/250/EEC of 15 June 1971 establishing Community methods of analysis for the official control of feeding-stuffs. Accessed Oct. 28, 2019. https: //op.europa.eu/en/publication-detail/-/publication/05e35b2a -7b20-4848-b12d-4ba402869fb7/language-en.

Hansen, B. 1989. Determination of nitrogen as elementary-N, an alternative to Kjeldahl. Acta Agric. Scand. 39:113-118. https://doi .org/10.1080/00015128909438504.

Hatew, B., S. C. Podesta, H. Van Laar, W. F Pellikaan, J. L. Ellis, J. Dijkstra, and A. Bannink. 2015. Effects of dietary starch content and rate of fermentation on methane production in lactating dairy cows. J. Dairy Sci. 98:486-499. https://doi.org/10.3168/jds.2014 $-8427$.

Hellwing, A. L. F., P. Lund, M. R. Weisbjerg, M. Brask, and T. Hvelplund. 2012. Technical note: Test of a low cost and animal-friendly system for measuring methane emissions from dairy cows. J. Dairy Sci. 95:6077-6085. https://doi.org/10.3168/jds.2012-5505.

Hindrichsen, I. K., and M. Kreuzer. 2009. High methanogenic potential of sucrose compared with starch at high ruminal pH. J. Anim Physiol. Anim. Nutr. (Berl.) 93:61-65. https://doi.org/10.1111/j .1439-0396.2007.00779.x.

Hindrichsen, I. K., H. R. Wettstein, A. Machmüller, B. Jörg, and M. Kreuzer. 2005. Effect of the carbohydrate composition of feed concentrates on methane emission from dairy cows and their slurry. Environ. Monit. Assess. 107:329-350. https://doi.org/10.1007/ s10661-005-3008-3.

Hindrichsen, I. K., H.-R. Wettstein, A. Machmüller, C. R. Soliva, K. E. Bach Knudsen, J. Madsen, and M. Kreuzer. 2004. Effects of feed carbohydrates with contrasting properties on rumen fermentation and methane release in vitro. Can. J. Anim. Sci. 84:265-276. https://doi.org/10.4141/A03-095.

Huhtanen, P., S. Ahvenjärvi, M. R. Weisbjerg, and P. Nørgaard. 2006. Digestion and passage of fibre in ruminants. Pages $87-135$ in $\mathrm{Ru}-$ minant Physiology. K. Sejrsen, T. Hvelplund, and M. O. Nielsen, ed. Wageningen Academic Publishers, Wageningen, the Netherlands.

Hymøller, L., A. L. F. Hellwing, P. Lund, and M. R. Weisbjerg. 2014. Milk production is unaffected by replacing barley or sodium hydroxide wheat with maize cob silage in rations for dairy cows. Animal 8:738-747. https://doi.org/10.1017/S1751731114000329.

Jentsch, W., M. Schweigel, F. Weissbach, H. Scholze, W. Pitroff, and M. Derno. 2007. Methane production in cattle calculated by the nutrient composition of the diet. Arch. Anim. Nutr. 61:10-19. https://doi.org/10.1080/17450390601106580.

Johnson, K. A., and D. E. Johnson. 1995. Methane emissions from cattle. J. Anim. Sci. 73:2483-2492. https://doi.org/10.2527/1995 $.7382483 x$.

Khalili, H., and P. Huhtanen. 1991. Sucrose supplements in cattle given grass-silage based diet. 2. Digestion of cell wall carbohydrates. Anim. Feed Sci. Technol. 33:263-273. https://doi.org/10 .1016/0377-8401(91)90065-Z.

Kirchgessner, M., H. L. Müller, F. Birkenmaier, and F. J. Schwarz. 1994. Energetishe Ververtung von Saccharose durch laktierende Milchkühe und Konsequenzen für die Energiebewertung von Zucker. J. Anim. Physiol. A. Anim. Nutr. 71:247-260. https://doi.org/ 10.1111/j.1439-0396.1994.tb00361.x. 
Kristensen, N. B., A. Storm, B. M. Raun, B. A. Røjen, and D. L. Harmon. 2007. Metabolism of silage alcohols in lactating dairy cows. J. Dairy Sci. 90:1364-1377. https://doi.org/10.3168/jds.S0022 -0302(07)71623-5.

Larsen, M., P. Lund, M. R. Weisbjerg, and T. Hvelplund. 2009. Digestion site of starch from cereals and legumes in lactating dairy cows. Anim. Feed Sci. Technol. 153:236-248. https://doi.org/10.1016/j .anifeedsci.2009.06.017.

Madsen, J., and T. Hvelplund. 1988. The influence of different protein supply and feeding level on $\mathrm{pH}$, ammonia concentration and microbial protein synthesis in the rumen of cows. Acta Agric. Scand. 38:115-125. https://doi.org/10.1080/00015128809436593.

Mertens, D. R. 2002. Gravimetric determination of amylase-treated neutral detergent fiber in feeds with refluxing in beakers or crucibles: Collaborative study. J. AOAC Int. 85:1217-1240.

Møller, J., R. Thøgersen, M. E. Helleshøj, M. R. Weisbjerg, K. Søgaard, and T. Hvelplund. 2005. Foddermiddeltabel - Sammensætning og foderværdi af fodermidler til kvæg. Rapport no. 112, Dansk landbrugsrådgivning. Dansk landbrugsrådgivning, Aarhus, Denmark.

Mortensen, B., F. Strudsholm, R. Thøgersen, M. R. Weisbjerg, and O. Toft. 1993. Ludbehandlet hvede og byg nedbrydes langsomt i vommen. Stor forskel mellem hvede og byg gør hvede mest interessant til ludbehandling. LK meddelelse nr. 21, 01-02-93. Dansk landbrugsrådgivning, Aarhus, Denmark.

Müller, H. L., F. Birkenmaier, F. J. Schwarz, and M. Kirchgessner. 1994. Energetische verwertung von futterrüben durch milchkühe. J. Anim. Physiol. Anim. Nutr. (Berl.) 71:234-246. https://doi.org/ 10.1111/j.1439-0396.1994.tb00360.x.

Murphy, M. R., R. L. Baldwin, and L. J. Koong. 1982. Estimation of stoichiometric parameters for rumen fermentation of roughage and concentrate diets. J. Anim. Sci. 55:411-421. https://doi.org/ $10.2527 /$ jas1982.552411x.

Myers, W. D., P. A. Ludden, V. Nayigihugu, and B. W. Hess. 2004. Technical note: A procedure for the preparation and quantitative analysis of samples for titanium oxide. J. Anim. Sci. 82:179-183. https://doi.org/10.2527/2004.821179x.

Norfor. 2019. Feed table. Accessed Feb. 20, 2019. http://www.norfor .info/feed-table/.

Nozière, P., I. Ortigues-Marty, C. Loncke, and D. Sauvant. 2010. Carbohydrate quantitative digestion and absorption in ruminants: From feed starch and fibre to nutrients available for tissues. Animal 4:1057-1074. https://doi.org/10.1017/S1751731110000844.

O'Mara, F. P., J. J. Murphy, and M. Rath. 1997. The effect of replacing dietary beet pulp with wheat treated with sodium hydroxide, ground wheat, or ground corn in lactating cows. J. Dairy Sci. 80:530-540. https://doi.org/10.3168/jds.S0022-0302(97)75967-8.

Owens, D., M. McGee, T. Boland, and P. O'Kiely. 2008. Intake, rumen fermentation and nutrient flow to the omasum in beef cattle fed grass silage fortified with sucrose and/or supplemented with concentrate. Anim. Feed Sci. Technol. 144:23-43. https://doi.org/ 10.1016/j.anifeedsci.2007.09.032.

Phipps, R. H., J. D. Sutton, D. J. Humphries, and A. K. Jones. 2001. A comparison of the effects of cracked wheat and sodium hydroxidetreated wheat on food intake, milk production and rumen digestion in dairy cows given maize silage diets. Anim. Sci. 72:585-594. https://doi.org/10.1017/S1357729800052115.

Pinares-Patiño, C. S., J. C. McEwan, K. G. Dodds, E. A. Cardenas, R. S. Hegarty, J. P. Koolaard, and H. Clark. 2011. Repeatability of methane emissions from sheep. Anim. Feed Sci. Technol. 166167:210-218. https://doi.org/10.1016/j.anifeedsci.2011.04.068.

Primdal, L., M. Johansen, and M. R. Weisbjerg. 2014. Do dairy cows have preferences for different concentrate feeds? Page 363 in Animal Production in Australia: Proc. 30th Biennial Conference of the Australian Society of Animal Production. S. Hatcher, G. L. Krebs, and B. W. B. Holman, ed.

Ramin, M., and P. Huhtanen. 2013. Development of equations for predicting methane emissions from ruminants. J. Dairy Sci. 96:24762493. https://doi.org/10.3168/jds.2012-6095.

Robinson, P. H., S. Taminga, and A. M. van Vuuren. 1987. Influence of declining level of feed intake and varying the proportion of starch in the concentrate on rumen ingesta quantity, composition and kinetics of ingesta turnover in dairy cows. Livestock Prod. Sci. $17: 37-62$.

Schürch, A. F., L. E. Lloyd, and E. W. Crampton. 1950. The use of chromic oxide as an index for determining the digestibility of a diet. J. Nutr. 41:629-636. https://doi.org/10.1093/jn/41.4.629.

Sjaunja, L. O., L. Baevre, L. Junkkarinen, J. Pedersen, and J. Setala. 1991. A Nordic proposal for an energy corrected milk (ECM) formula. Pages 156-157 in Performance Recording of Animals: State of the Art. EAAP publication no. 50. P. Gaillon and Y. Charbert, ed. Pudoc, Wageningen, the Netherlands.

Stensig, T., M. R. Weisbjerg, and T. Hvelplund. 1998. Digestion and passage kinetics of fiber in dairy cows as affected by the proportion of wheat starch and sucrose in the diet. Acta Agric. Scand. 48:129-140.

Stoldt, W. 1952. Vorschlag zur Vereinheitlichung der Fettbestimmung in Lebensmitteln. Fette und Seifen. 54:206-207. https://doi.org/10 .1002/lipi.19520540406.

Tilley, J. M. A., and R. A. Terry. 1963. A two stage technique for the in vitro digestion of forage crops. J. Br. Grassl. Soc. 18:104-111. https://doi.org/10.1111/j.1365-2494.1963.tb00335.x.

Ungerfeld, E. M., and R. A. Kohn. 2006. The role of thermodynamics in the control of ruminal fermentation. Pages 55-85 in Ruminant Physiology: Digestion, Metabolism and Impact of Nutrition on Gene Expression, Immunology and Stress. K. Sejrsen, T. Hvelplund, and M. O. Nielsen, ed. Wageningen Academic Publishers, Wageningen, the Netherlands.

Vallimont, J. E., F. Bargo, T. W. Cassidy, N. D. Luchini, G. A. Broderick, and G. A. Varga. 2004. Effects of replacing dietary starch with sucrose in ruminal fermentation and nitrogen metabolism in continuous culture. J. Dairy Sci. 87:4221-4229. https://doi.org/10 .3168/jds.S0022-0302(04)73567-5.

Volden, H. 2011. NorFor-The Nordic Feed Evaluation System. EAAP publication no. 130. Wageningen Academic Publishers, Wageningen, the Netherlands.

Weisbjerg, M. R., H. Gado, T. Hvelplund, and B. B. Jensen. 1999. The effect of easily fermentable carbohydrates and $\mathrm{pH}$ on fiber digestibility and VFA pattern in an in vivo continuous culture system. S. Afr. J. Anim. Sci. 29:112-113.

Weisbjerg, M. R., T. Hvelplund, and B. M. Bibby. 1998. Hydrolysis and fermentation rate of glucose, sucrose and lactose in the rumen. Acta Agric. Scand. 48:12-18.

Zinn, R. A., and F. N. Owens. 1986. A rapid procedure for purine measurement and its use for estimating net ruminal protein synthesis. Can. J. Anim. Sci. 66:157-166. https://doi.org/10.4141/ cjas86-017.

\section{ORCIDS}

C. F. Børsting (® https://orcid.org/0000-0001-6915-5332

M. Brask @ https://orcid.org/0000-0001-7164-2893

A. L. F. Hellwing (ํ) https://orcid.org/0000-0002-2881-399X

M. R. Weisbjerg (ํ) https://orcid.org/0000-0002-6514-9186

P. Lund ๑ https://orcid.org/0000-0002-9113-4500 